This full text version, available on TeesRep, is the PDF (final version) of:

Carroll, R. (2000) 'Return of the century: Time, modernity and the end of history in Angela Carter's Nights at the Circus', Yearbook of English Studies, 30, pp.187-201.

For details regarding the final published version please click on the following link:

http://www.jstor.org/stable/3509252

When citing this source, please use the final published version as above.

This document was downloaded from http://tees.openrepository.com/tees/handle/10149/96378 Please do not use this version for citation purposes.

All items in TeesRep are protected by copyright, with all rights reserved, unless otherwise indicated. 


\title{
Return of the Century:
}

Time, Modernity, and the End of History in

\author{
A nge 1 a Carter's Nights at the Circus \\ R A C H E L C A R R O L L \\ University of Teesside
}

The very idea of modernity is closely correlated with the principle that it is both possible and necessary to break with tradition and institute absolutely new ways of living and thinking.

We now suspect that this 'rupture' is in fact a way of forgetting or repressing the past, that is, repeating and not surpassing

(Jean-François Lyotard)

Set at 'the cusp of the modern age, the hinge of the nineteenth century', Nights at the Circus, ${ }^{2}$ Angela Carter's fin de siècle fantasy anticipates the new century as an era of radical transformation and change. However, it is also a text fascinated with modernist myths of origin: from the threshold of the twentieth century it returns to the 'prehistory' of the modern, as constructed by modernism, represented by such motifs as animals, folk and peasant culture, childhood, the wilderness of Siberia, and the colonial 'others' of empire. In The End of Modernity, Gianni Vattimo argues that modernity is 'dominated by the idea that the history of thought is a progressive "enlightenment" which develops through an ever more complete appropriation and reappropriation of its own foundations':

These [foundations] are often also understood to be 'origins', so that the theoretical and practical revolutions of Western history are presented and legitimated for the most part as recoveries, rebirths, or returns. ${ }^{3}$

A return to origin could be read, then, as evidence of a complicity with the forgetting and repressing of origins; a forgetting and repressing which functions as a condition of a subsequent recovery, rebirth or return. Such a reading, however, would seem difficult to reconcile with the fact that in

'Jean-François Lyotard, 'Note on the Meaning of "Post-" ', in Postmodernism: A Reader, ed. by Thomas Docherty (Hemel Hempstead: Harvester Wheatsheaf, 1993), p. 48

Nights at the Circus (London: Picador, 1985), p. 265

The End of Modernity: Nihilism and Hermeneutics in Post-modern Culture (Cambridge: Polity Press, 1988), p. 2. 
terms of aesthetic style, Nights at the Circus is an exemplary postmodern text: the textuality of history is self-consciously evoked by the historical and literary pastiche in which it revels. Indeed, if Carter's interrogation of history did not extend beyond the playful provocations of pastiche her writing would be vulnerable to the charge commonly, and evenjustifiably, made against postmodern fiction: that it reduces history to a travesty of parodic gestures and costumes and that it evades a more complex and ethical encounter with the otherness of the past.

I wish to suggest that Carter's text could be read as most interesting, and most postmodern, not in its representation of history but in its rendering of time. Postmodern, that is, in the sense that Vattimo gives. Vattimo argues that the project of modernity is a process of return and overcoming, whereas postmodern thought is characterized by a critique of Western thought and of the very notion offoundation: it is a critique without overcoming, a taking leave of the logic of modernity. It is in this sense that the postmodern marks the 'end of history' in that it relinquishes an understanding of history as a linear sequence ofradical breaks or ruptures. Vattimo traces this postmodern critique to Nietszche and Heidegger, a gesture which is only anachronistic if the postmodern is defined as a historical break from the modern. In its attempt to give a materialist and symbolic rewriting of modernity, ${ }^{4}$ Nights at the Circus suggests the implication of the unconscious in history, and of history in the unconscious. As discourses ofmodernity, Marxism and psychoanalysis share a fascination with origins: the origins of identity and the origins of history. Carter's text makes possible an understanding of these discourses as making a return without overcoming. Forboth Marxis m and psychoanalysis, the present is constituted by the unresolved conflicts of the past.

A double dynamic is in motion in Carter's text: a return to origin, to the past, the archaic, the 'primitive', and a projection into the future. This departure from the past is signified by motifs of passage; the picaresque narrative is transported through space by means of the railway, while it traverses time and history by means ofmemory. Tableaux scenes of the past, unmoored from their lodgings and set adrift in time, announce a sense of historical transition. The destination of unfolding time is made the subject of magical intervention; discontinuities and anachronisms disrupt the logic of time and history. Both the obsolescence of the past and the assumed course of the future are called into question. Encounters with the archaic and the 'primitive' transform endings by exploding 'origins'. Moreover, the catastrophic blow which the train crash delivers is the culmination of the succession of traumas which punctuate the course of the narrative. Nights at the Circus holds a wake for the past: the narrativejourneys towards a radically

The narrative alternates between a materialist analysis of oppression by gender, race, and class, as given by Lizzie, and the fairy tales, family romances, and uncanny encounters associated with Fevvers. 
'other' space and time, arriving at the threshold of the 'somewhere, elsewhere' (p. 249) of Utopia.

Locomotive of history: departures and returns

[In the] early stage of industrial nature it is no accident that early modernity feels an affinity for the primitive and the archaic.

Susan Buck Morss

As the dawning of the new century approaches, the narrative plunges off the edge of the known world. As the railway carriages of the Trans-Siberian Express, by which the circus is travelling, are thrown from their tracks, a narrative launched by the irrepressible momentum of Fevvers's rhetoric is seemingly derailed; its trajectory into the future arrested in the suspended temporality of a state of nature. As a vehicle which traverses states of consciousness and centuries, the train is an agent of this transformation.

Carter harnesses the peculiar symbolism of the train as noted by Susan Buck-Morss. Buck-Morss records that the identification of spatialmovement with historical progress rendered the train an icon of modernity: 'Railroads were the referent, and progress the sign, as spatial movement became so wedded to the concept of historical movement that these could no longer be distinguished' (p. 91). In Nights at the Circus the paradox that the vehicle of modernity returns its passengers to a state of origin heralds uncanny encounters between the archaic and modern, the primitive and the technologically advanced. These encounters convey the narrative's investment in moments of historical transition.

The history of the development of the train reveals that as a transitional innovation, its unprecedented appearance was mediated through the very irrational beliefs which the scepticism of the modern era sought to render redundant. ${ }^{6}$ Emerging at the beginnings of industrial capitalism, its first designs emulated the motion of the organic forms it was designed to replace These 'iron horses' progressed by means of 'feet' which were lifted alternately in mimicry of its animal alter ego. This animistic quality lends the train the fantastic properties attributed to the horse: in Nights at the Circus, its 'rocking horse rhythm' (p. 200) anticipates the shaman's travels through altered states.

The technology of the train is intent on a rapid departure from organic means of transport. The return which is witnessed, however, is perhaps not so much a return to the natural world as a return of the natural world

The Dialectics of Seeing: Walter Benjamin and the Arcades Project (London: Massachusetts Institute of Technology Press, 1989), p. 70

I have drawn on the work of a number of authors for this symbolic history of the train, including Susan Buck-Morss, Hal Foster, and Wolfgang Schivelbusch. 
repressed by the mastery of science. In his study of the significance of the experience of railway travel in the nineteenth century, Wolfgang Schivelbusch illustrates the 'disorientation experienced by the traditional spacetime consciousness when confronted by the new technology' by quoting Heinrich Heine: I feel as if the mountains and forests of all countries were advancing on Paris. Even now, I can smell the German linden trees; the North Sea's breakers are rolling against my door." Heine's remarkable vision of creeping forests and flood suggests the uncanny return of nature from repression. Susan Buck-Morss comments on the paradox that modern innovations took the form of 'historical restitutions':

Early photography mimicked painting. The first railroad cars were designed like stage coaches, and the first electric light bulbs were shaped like gas flames. Newly processed iron was used for ornament rather than structural supports, shaped into leaves, or made to resemble wood. Industrially produced utensils were decorated to resemble flowers, fauna, seashells, and Greek and Renaissance antiques, (pp. 110-11)

Indeed, Fevvers comments on the incongruity of travelling through a 'preAdamite world' in the splendour of an 'Empire drawing room' (Nights at the Circus, p. 199): she views the barren landscape through tassels and brocade, a frame which echoes a sequence of façadesin the novel. Fevvers is herselfa monstrous hybrid thrown up by the age of revolutions. Her radical indeterminacy invokes not only the absolutely inanimate machine but the organic inertia of wood, once vital and growing, now dead and still: 'Her face [. . . ] might have been hacked from wood and brightly painted up by those artists who build carnival ladies for fairgrounds or figureheads for sailing ships' (p. 35). The 'lumber room of femininity' (p. 69), to which Fevvers is consigned in Madame Schreck's establishment, is suggestive both of the unconscious and of the outmoded. That lumber denotes timber in particular seems indicative of a society in transition. To evoke wood in the context of the origins of industrial capitalism is to recall how the 'new nature' of technology not only masters and usurps the organic world but renders it redundant. ${ }^{8}$ Wood characterizes a whole consciousness about to be transformed. Schivelbusch quotes Sombart: 'So general was its use in the production of material goods that the characteristics of culture before the eighteenth centurywere decidedly wooden' (p. 1). In Fevvers's 'woodenness', the barely departed past makes an uncanny return.

That the technological innovations of modernity are approached through the circus indicates the proximity of automation and animism, of the

Wolfgang Schivelbusch, The Railway Journey: Trains and Travel in the Nineteenth Century, trans, by Anse $1 \mathrm{~m}$ Hollo (Oxford: Blackwell, 1977), p. 44.

Buck-Morss outlines a concept of 'new nature', a term which Adorno uses to describe Walte Benjamin's dialectical understanding of 'natural history': 'There have been, then, two epochs of nature. Thefirstevolved slowly over millions of years; the second, our own, began with the industrial revolution, and changes its face daily. This new nature, its powers still unknown, can appear ominous and terrifying (p. 70) 
machine and the marvellous. While the train is one form of new technology caught up in animistic thought as the 'iron horse', another defining modern innovation which emerges through the patronage of outmoded beliefs is photography. Herr M., a 'scientist manqué' (p. 135), employs photography in the service of spiritualism. Characterized by supernatural illusion and magic, this new science is cloaked in the superstitions of the seance and spiritrapping. Ernst Bloch evokes this paradoxical conjunction in his reference to the 'new magic of mechanism, the cold enchantment'.' Indeed, Herr M. performs a morbid religious ritual by raising the dead from the other world. It seems as if the science of photography is too early to be assimilated; the return of the dead is perceived as more probable than the technical reproduction of images.

Schivelbusch offers an insight into the assumption by modern innovations of disguising façades. Accounting for the excessive upholstery of the railway interior, he suggests that it reveals a function other than that of comfort: its function is to camouflage the industrial origins of bourgeois wealth and privilege. Moreover, it is designed to conceal from the passenger his absorption into the circulation of goods like any other inanimate object. As Schivelbusch writes:

the jolt to be softened is no longer physical but mental: the memory of the industrial origin of objects, from railway stations or exhibition halls constructed out of steel, to chairs constructed out of wood. The opulent baroque and Renaissance fronts that cover the steel girders are nothing but, on a larger scale, the braided and tasseled upholstery cushions that render the true construction of the armchair or sofa invisible and thus forgettable, (p. 124)

Hence, the railway is not only a symbol oftransition between 'old' and 'new' nature; it is an agent of the crisis of subjectivity which modernity inaugurates. Indeed, the railway does inflict a 'jolt' of profound proportions: it initiates the human body into the modern era by its revolutionary technological achievement, the 'annihilation oftime and space' (Schivelbusch, p. 13). The bourgeois interior of the carriage conspires with the apparently effortless passage of the locomotive to assure the traveller that s/he has not left home. However, the hurtling pace with which the engine thrusts its cargo into other times and places attests to the violence immanent in the explosive changes of modernity. The force latent in this 'annihilation' reveals its power in the train crash in Nights at the Circus, which shatters identity as well as time and space.

The experience of rail travel played a suggestively significant role in the development of an eminently modern condition: the condition of shock. Carter evokes this conjunction of modernity and shock when she describes Walser as a 'kaleidoscope equipped with consciousness' (p. 10): her phrase irresistibly recalls Walter Benjamin's model, taken from Baudelaire, of the 
consciousness assailed by the shocks of modernity as a 'kaleidoscope equipped with consciousness'. ${ }^{10}$ The history of clinical theories of shock reveals that they originated in the nineteenth century with accounts of the delayed symptoms suffered by survivors of railway accidents. Freud himself employed such a collision to illustrate his theory of latency in 'Moses and Monotheism'." Hal Foster has remarked upon the significance of this surprising encounter between the origins of industrial technology and the origins of psychoanalytic theory:

The discourse of shock was developed in the nineteenth century partly in relation to railway accidents, the traumatic effects of which were regarded first physiologically, then psychologically, and finally psychoanalytically. In short, shock is an alternate route to the unconscious, the discovery of which is so often traced first to hysteria, then to dreams. ${ }^{12}$

To read the railway as the alternate 'royal road' to the unconscious is to begin to comprehend its significance in Carter's narrative: it is a route to other worlds of consciousness, both subjective and historical."

Travel is the metaphor through which the persistence of the past is revealed. Ernst Bloch's assertion that 'not all people exist in the same Now' (p. 97), which is made within the scheme of his Utopian Marxist philosophy, might be the password to the narrative of Nights at the Circus. ${ }^{\prime 4}$ Bloch traces a course of history which exceeds the single track of determinism typified by the railroad and its hurtling progress over mastered ground:

History is no entity advancing along a single line, in which capitalism for instance, as the final stage, has resolved all the previous ones; but it is a polyrhythmic and multispatial entity, with enough unmastered and as yet no means revealed and resolved corners, (p. 62; Bloch's italics)

The transforming magic inflicted on 'authentic history' (Nights at the Circus, p. 97) amounts to the conjuring of these 'polyrhythmic and multispatial' dimensions as if from the unconscious. The touring circus is the convoy within which this journey through time is undertaken in Nights at the Circus. It is both archaic and enchanted in its resemblance to the itinerant fair of

Walter Benjamin, 'On Some Motifs in Baudelaire', Illuminations, trans, by Harry Zohn (1968; repr. London: Fontana, 1992), p. 171.

Freud defines latency as follows: 'the emergence of unintelligible manifestations calling for an explanation and an early, and later forgotten, event as a necessary determinant', 'Moses and Monotheism', Standard Edition of the Complete Psychological Works: Volume XXIII, trans, by James Strachey (London: Hogarth, 1961), p. 72. See also Cathy Caruth, 'Unclaimed Experience: Trauma and the Possibility of History', in Unclaimed Experience: Trauma, Narrative and History (Baltimore, M D, and London: Johns Hopkins University Press, 1996).

Compulsive Beauty (Cambridge, M A : Massachusetts Institute of Technology Press, 1993), pp. 48-49.

'The interpretation of dreams is the royal road to a knowledge of the unconscious activities of the mind', Sigmund Freud, 'The Interpretation of Dreams', Standard Edition of the Complete Psychological Works of Sigmund Freud: Volume V, trans, by James Strachey (London: Hogarth, 1961), p. 608.

'Hope prefigures a happy ending that is not yet here, but the fairy tale can make the reader aware of it. The story of adventure with which Bloch compares it produces a similar effect, as it is marked by disturbances, interruptions of order. Travel, the knowledge of other and distant places, finds its space as and in these interruptions', Liliane Weissberg. 'Philosophy and the Fairy Tale: Ernst Bloch as Narrator', New German Critique, 55 (1992), 21-44 (p. 32). 
centuries past, which traversed the limited horizons of its audience, passing over lands so remote that they may well have crossed oceans or even centuries. A 'dream ship moor[ed] on the dusty squares' (Bloch, p. 159), the circus carries a cargo from other lands and times.

Traumas of dispossession and exile are discovered by the narrative of Nights at the Circus as it journeys into the past. However, it is through the painful and difficult encounter between hopeful travel and the nightmares of history that a destination in the future is approached. The industrial revolution ushers in a new time scale: in Marx's terms, it renders all that precedes it 'prehistory'. ${ }^{15}$ The 'return' which Carter's narrative takes is not a repudiation of history. On the contrary, a return is undertaken in order to arrive in the future; it is out of this paradox that the explosive Utopian energies of the narrative emerge. History inflicts on the consciousness of the human subject in the modern era a sequence of shocks and repressions without precedent, either in severity or in compression. That Nights at the Circus is set within this history is significant because the narrative engages with its transformative potential. Its energies are invested in the revolutions which are, according to Marx, the 'locomotives ofworldhistory'. ${ }^{16}$

Homesickness for the future

The audacious trajectory of Fevvers's voice which launches the narrative seems to be diverted by obsessive returns to the past. When the novel is plunged into the primal wilderness it initially appears that a millennialvision of the future has been replaced by the inescapability of origin. Uneasily, the narrative regresses, succumbing to the dead time of the state of nature, as if disillusion with the progress of history has borne a nihilistic primitivism. However, the backward glance which arrests the novel, suspending time and transfixing the 'locomotive of history', might be interpreted as the culmination of a keening homesickness that pervades the novel. ${ }^{7}$ This is not a homesickness which pines for the restitution of an idyllic state comparable to childhood. Indeed, in Nights at the Circus, childhood is a perilous state afflicted by neglect and abuse: Fevvers's youth is marked by abandonment and abduction; both Mignon and Ivan witness parental violence and murder; Mignon suffers destitution and exploitation by Herr M.; the circus stable boy flees persecution for his sexual identity only to be murdered by the Strong Man. There are no homes in Nights at the Circus, as its world is one of dispossession; the profound longing of the backward glance denotes a desire to construct a home in the fabric of the future.

Marx quoted in Buck-Morss, p. 64

Marx quoted in Buck-Morss, p. 92.

The image of the suspended train recalls Rene Magritte's 'Time Suspended'. Moreover, the engine stalled in the wilderness and absorbed into nature evokes the 'photograph of a speeding locomotive abandoned for years to the delirium of a virgin forest' with which Breton illustrated his concept of 'convulsive beauty' (quoted in Foster, p. 25). 
The dreaming of 'elsewheres', most poignantly expressed in Mignon's rendition of Schubert's 'Kennst Du Das Land', ${ }^{18}$ does not convey a fatalistic melancholy so much as a radical yearning for the future: it is a nostalgia for a Utopian future anticipated but not yet comprehended. Christopher Norris notes that Utopian thought is conventionally dismissed as 'a kind of infantile disorder, an escape from the realities of social existence'." However, the history of homes in Carter's narrative ensures that sentimental nostalgia cannot exert its insipid spell over the brutal reality of experience. The state signified by 'home' occupies a powerful place in Utopian thinking: it is described by Theodor Adorno as 'the house in which one would be at home, inside, no longer estranged'. ${ }^{20}$ Adorno is describing its significance in the philosophy of Ernst Bloch, who transforms a subjective affect into a vehicle of materialist enlightenment:

Once man has comprehended himself and has established his own domain in real democracy, without depersonalisation and alienation, something arises in the world which all men have glimpsed in childhood: a place and a state in which no one has yet been. And the name of this something is home."

The backward glance, in this account of Utopian thought and in the narrative of Nights at the Circus, is a safeguard against forgetfulness. It prepares the way for the future by confronting the contradictions of the past. As Susan BuckMorss writes:

A construction of history that looks backward, rather than forward, at the destruction of material nature as it has actually taken place, provides dialectical contrast to the futurist myth of historical progress (which can only be sustained by forgetting what happened), (p. 95)

Bloch's 'home' is both familiar and unknown; familiar to the Utopian yearnings of humanity throughout time, but unknown as it has yet to be made a reality..$^{2}$

A concept of history which emphasizes the recovery of the past, the persistence of memory, and the importance of remembering, has an affinity with the project of psychoanalytic thought. Commenting on this analogy, Maud Ellmannfirst notes the pervasive 'prohibition of the backward glance'

\footnotetext{
" Carolyn Steedman suggests a resemblance between Schubert's 'Kennst Du Das Land' and 'Home Sweet Home', and explores the motivation behind a widespread scholarly impulse to identify Mignon 'The search for Mignon's origins [... ] is about the desire to give the child a home: to find her a home in the world: to give her a history, a psychology', 'New Time: Mignon and her Meanings', in Fin de Sièclel Fin $d u$ Globe: Fears and Fantasies of the Late Nineteenth Century, ed. by John Stokes (London: Macmillan, I992), p.111

'Marxist or Utopian? - The Philosophy of Ernst Bloch', Literature and History, 9.2 (1983), 240-45 (p. 240).

20 'Ernst Bloch's "Spuren": On The Revised Edition of 1959', in Notes to Literature: Volume One (New York: Columbia University Press, 1991), p. 205.

Ernst Bloch, On Karl Marx (New York: Herder and Herder, 1971), pp. 44-45

See Anson Rabinbach, 'Unclaimed Heritage: Ernst Bloch's Heritage OfOur Times and the Theory of Fascism', New German Critique, I I (1977), 5-21: '[It is] a critique of nihilism and a restoration of Utopia to its original meaning as an immanent force, a 'waking dream' of the possible. [...] Nihilism accepts only the homelessness of mankind and resigns itself before the loss of the other worldly' (pp. 7-8).
} 
in the classical mythology to which Freud's writing is so indebted: 'Lot's wife turns into a pillar of salt when she looks back at her homeland left behind; Orpheus is permitted to conduct Eurydice out of the underworld only under the condition that he does not look back at her. ${ }^{23}$ The revolution effected by psychoanalysis is to defy this prohibition: a return to the past is ventured which braves the risk of blinding and dismemberment. Ellmann writes that it is in the 'process of discovery rather than the crimes revealed' that the power of psychoanalysis resides: 'Its terror lies in the interpretative activity itself, the sheer audacity of looking back into the past and rediscovering the violence of childhood' (pp. 8-9).

As Carter's narrative leaves London, Walser adopts the tone of a dilettantish host ('let me invite you to spend a few nights at the circus' (p. 91)), as if assuming the role of a master of ceremonies presiding over scenes of trifling diversion. Indeed, a panoramic procession of scenes from the past is summoned as if projected by a magic lantern. ${ }^{4}$ However, the catastrophe of the railway crash explodes any sense of complacent spectatorship. Moreover, it is the culmination of glimpses of horror on which the course of the narrative has already stalled. Incidental to the picaresque progress of the novel is a sequence of scenes of women's oppression. These tableaux represent images ofwomen frozen in postures of subjection. Fevvers boards the train to escape assimilation into the Archduke's collection of automata; the train is identical to the miniature model revealed in the final Fabergé-style egg. ${ }^{25}$ The vestal hearth of Ma Nelson's rational brothel, with its 'brace ofbuxom, smiling goddesses' (p. 26), is succeeded by the crypt and 'black theatre' (p. 61) of Madame Schreck's 'museum of woman monsters' (p. 55)' who stand in 'profane altars' (p. 61), by Rosencreutz's Gothic mansion in which Fevvers's symbolism renders her expendable, by the alcove in which Mignon 'impersonate[s] the dead' (p. 138), and by the cells 'lit up like so many small theatres' (p. 211) in the women's asylum.

These suspended figures are held captive by a Gothic narrative of persecution and imprisonment to which Fevvers's childhood career as a 'living statue' belongs: Fevvers admits, 'I played the living statue all my girlhood' (p. 26). Walser's hypothesis that Fevvers may be a 'marvellous machine' (p. 29) or 'an ingenious mechanism' (p. 43), conjures such figures as Pygmalion's image and E. T. A. Hoffmann's Olympia, uncanny statues and dolls which attest to the deadly inertia of femininity. The visionary brothel-keeper, Ma Nelson, casts Fevvers as 'Victory with Wings': an image

Introduction, Psychoanalytic Literary Criticism, ed. by Maud Ellmann (London: Longman, 1994), p. 9. 'As the traveler steps out of that space, it becomes a stage setting, or a series of such pictures or scenes created by the continuously changing perspective. Panoramic perception, in contrast to traditional perception, no longer belongs to the same space as the perceived objects' (Schivelbusch, p. 66).

This egg has a historical precedent. Fabergéwere commissioned to present the Tsarina and Dowager Empress with Easter eggs every year: an egg containing a model of the Trans-Siberian Express was crafted to commemorate its opening. See Sofka Zinovieff, 'The Jewel in the Crowd: How Fabergé's Extraordinary Art of the Ordinary Heralded the End for European Nobility', Times Literary Supplement, 18 February 1994, pp. $16-17$. 
of woman triumphant. However, this guise is experienced as a kind of live burial in the shell from which she emerged. The make-up and costume form an 'artificial egg', a 'death mask', and a 'sarcophagus' (p. 39). It is this image which Madame Schreck appropriates and converts into the Angel of Death. Fevvers undergoes an even more literal live burial within Schreck's crypt, known both as Down Below and as The Abyss, which is a symbol offemale sexuality in this house of terrors.

Perhaps the most chilling ordeal which Fevvers endures is inflicted by the Grand Duke, who appears to take literally the rumour that she is not a woman but a 'cunningly constructed automaton made up of whalebone, india-rubber and springs' (p. 147): he plots to induct her into his collection of mechanical toys. ${ }^{26}$ These figures represent creatures curiously in bondage to their own bodies. The bird whose beak is replaced by a flute is possibly a nightingale and so evokes the image of the raped and mutilated Philomel and her agony of stolen speech. The woman-harp's strings in place of her torso make a similarly brutalized music from the wound-like absence where her breasts, belly, and hips should be. However, the automaton is here less marvellous than alienating. The 'black theatre' of Madame Schreck's brothel, whose very name evokes a dark romanticism, belongs to the grotesque as defined by Wolfgang Kayser. This grotesque characteristically confounds the animate and inanimate:

The mechanical object is alienated by being brought to life, the human being by being deprived of it. Among the most persistent motifs of the grotesque we find human bodies reduced to puppets, marionettes, and automata, and their faces frozen into masks. ${ }^{27}$

The uncanny automata signify a peculiarly modern alienation prompted, perhaps, by the steadily advancing usurpation of the machine: that is, the 'living statue' which threatens to eclipse human agency. ${ }^{28}$

Bakhtin writes of the grotesque image that it 'reflects a phenomenon in transformation, an as yet unfinished metamorphosis'. ${ }^{29}$ He denies the

\footnotetext{
${ }^{26}$ The Archduke's puppet musicians in Nights at the Circus resemble Jacques Vaucanson's famous automata, a flautist, drummer, and duck, which were presented to the Académie Royale Des Sciences in 1738; objects of wonder and incredible technical skill, they represented a union of fantasy and technology. Indeed, Jean-Claude Beaune has written of the earliest automata that they represented 'the dream, the ideal form, the Utopia of the machine, which endows them from the first with an anthropomorphous or living quality', 'The Classical Age of Automata: An Impressionistic Survey From The Seventeenth Century to the Nineteenth Century', trans, by Ian Patterson, in Fragmentsfor a History of the Human Body: Part One, ed. by Michel Feher with Romona Naddaff and Nadia Tazi (London: Massachusetts Institute of Technology Press, 1989), p. 431.

Wolfgang Kayser, The Grotesque in Art and Literature, trans, by U l rich Weisstein (Bloomington: Indiana University Press, 1963), p. 183

" Hal Foster points out that the 'marvellous machines' of Enlightenment invention and the origins of mass manufacture meet in the figure of Vaucanson: Vaucanson was also the designer of a silk factory in 1756 which is considered to be the first modern industrial plant.

29 Mikhail Bakhtin, Rabelais and his World, trans, by Helene Iswolsky (Bloomington: Indiana University Press, 1984), p. 24.
} 
modern grotesque the subversive power which he attributes to the Renaissance carnivalesque, whose subsequent decline he ascribes to the legacy of Romanticism:

The world of Romantic grotesque is to a certain extent a terrifying world, alien to man. A11 that is ordinary, commonplace, belonging to everyday life, and recognised by all suddenly becomes meaningless, dubious and hostile. Our own world becomes an alien world. Something frightening is revealed in that which was habitual and secure, (pp. 38-39)

Bakhtin seems to attribute this sense of alienation to a wilful distortion on the part of the Romantic imagination. However, it could be argued that Romanticism is here anticipating a sense of alienation which is characteristic of the emerging modern world; what appears, in all its novelty and idiosyncracy, to be a perverse subjective experience carries a historical dimension. Bakhtin does seem to acknowledge this quality when he writes that 'the grotesque, including the Romantic form, discloses the potentiality of an entirely different world, of another order, another way of life' (p. 48).

Bakhtin's work is inflected with a powerful and often lyrical nostalgia for a lost world: Nights at the Circus is a fiction similarly preoccupied with Utopia but one which incorporates a scepticism about both nostalgia and futuristic prescription. It seeks to approach the future through the contradictions of the past. In Nights at the Circus, each framed scene is shed by the narrative progress of the novel. Through this sacrifice each oppression is shown to be contingent, an ideological illusion which will vanish with the cessation of belief. Ma Nelson's brothel, about to be turned into a home for fallen women, is seen to 'waver' and 'dissolve' (p. 49) and is committed to a sacrificial funeral pyre. Madame Schreck similarly vanishes, leaving only dry bones within her clothes as if she had been 'agitated only by the power of an infernal will' (p. 84). Fevvers escapes both Rosencreutz and the Grand Duke by an act of the supernatural which supersedes any temporal exercise of power. Finally, the 'army of lovers' break the spell of their confinement simply by 'one, great united look of accusation' (p. 218), as if to return the look of the oppressor and escape the subjection of the gaze is an act as invested with magical power as the act of naming.

The staging and banishing of these dramas might be modelled upon the outline ofrevolutionary historical progress articulated in Marx's 'Eighteenth Brumaire of Louis Bonaparte'. Marx famously asserts that the 'tradition of all the dead generations weighs like a nightmare on the brain of the living'. ${ }^{30}$ He implies that in order to achieve a revolution which is genuinely radical, the ghosts of past oppression must be exorcised; it is to this end that the past is revisited in Garter's narrative. Nights at the Circus is certainly haunted by

${ }^{30}$ Karl Marx, 'The Eighteenth Brumaire of Louis Bonaparte', in Selected Works (London: Laurence and Wishart, 1968), p. 96. 
history, though some of its ghosts are not yet dead and one significant spectre is about to be born. ${ }^{3}$

At the turn of the twentieth century, the rapid and escalating pace of modernity consigns even the recent past, that of the preceding generation to historical redundancy. For Benjamin, the peculiar enchantment of outmoded forms in the disenchanted modern world attests to the haunting power of the past and the radical potential of the irrational. ${ }^{32}$ Benjamin attributes the discovery of the category of the outmoded to André Breton and the Surrealists, who enlisted both Freud and $\mathrm{Marx}$ to their avant garde project. The Surrealists returned with wonder to the lost world of their childhood. This return echoes throughout Garter's narrative, which is itself set within the metamorphic transition of the nineteenth century into the modern era: that is, the mythical world of the Surrealists' childhood. ${ }^{33}$ Benjamin writes:

[Breton] was the first to perceive the revolutionary energies that appear in the 'outmoded', in the first iron constructions, the first factory buildings, the earliest photos, the objects that have begun to be extinct. [...] No one before these visionaries and augurs perceived how destitution - not only social but architectonic, the poverty of interiors, enslaved and enslaving objects - can be suddenly transformed into revolutionary nihilis m. ${ }^{34}$

These are the interiors of Fevvers's youth, past but not dead; they still cast such a baleful spell that to return to them, even in memory, is to undergo a harrowing of the past. The compressed force of history lies revealed in the 'outmoded': in the outmoded is revealed modernity's capacity to throw up revolutions in form and to consign them swiftly to extinction.

Benjamin's 'One-Way Street' tours the densely claustrophobic bourgeois home by nauseous gaslight. The apprehension of ill-concealed secrets is comparable to that evoked by the damasked, velvet interior of Ma Nelson's

\footnotetext{
31 'A spectre is haunting Europe - the spectre of Communism', Karl Marx and Friedrich Engels, The Communist Manifesto (London: Penguin, 1967), p. 78.

Margaret Cohen designates Benjamin's thought 'Gothic Marxism': the term describes a 'genealogy fascinated with the irrational aspects of social process, a genealogy that both investigates how the irrational pervades existing society and dreams of using it to effect social change' (Profane Illuminations. Walter Benjamin and the Paris of Surrealist Revolution (London: University of California Press, 1993), pp. 1-2).

In 'The Alchemy of the Word', Carter professes an affinity with Surrealism; the range of the marvellous in the narrative of Nights at the Circus certainly seems infused with a Surrealist spirit: 'Surrealism celebrated wonder, the capacity for seeing the world as if for the first time which, in its purest state, is the prerogative of children and madmen, but more than that, it celebrated wonder itself as an essential means of perception. Yet not a naive wonder. The surrealists did not live in naive times. A premonition of the imminent end of the world is always a shot in the arm for the arts; if the world has, in fact, just ended, what then? The 1914-18 war was, in many respects, for France and Germany, indeed the end of the world. [. . . However, the Russian Revolution of 1917 suggested the end of one world might mark the commencement of another world' (Expletives Deleted: Selected Writings (London: Chatto and Windus, 1992), p. 67). In the 'somewhere, elsewhere' (Nights at the Circus, p. 249) of Carter's text, there might be heard an echo of the concluding declaration of Breton's 1924 'Manifesto of Surrealism': 'Existence is elsewhere' (André Breton, Manifestoes of Surrealism, trans, by Richard Seaver and Helen R. Lane (Ann Arbor, M I : University of Michigan Press, 1972) p. 47

'Surrealism: The Last Snapshot of the European Intelligentsia', in One-Way Street and Other Writings, trans, by Edmund Jephcott and Kingsley Shorter (London: Verso, 1979), p. 229
} 
brothel and, moreover, the draped and bandaged façade of Madame Schreck's 'black theatre': 'What things were interred and sacrificed amid magic incantations, what horrible cabinet of curiosities lies there below, where the deepest shafts are reserved for what is most commonplace' (Benjamin, p. 46). Carter's 'cabinet of curiosities' is the 'lumber room of femininity'. It is visited by men who are pillars of the establishment and who act out their authority in perverse form beneath the foundations of Victorian propriety. Benjamin's 'horror of apartments' also evokes the cruelties inflicted in Nights at the Circus, amid dense curtains and shadowy alcoves, by Herr M. The suffocating interiors surreptitiously extinguish life just as surely as the epidemics out of which Herr M.'s ghost photography profits:

The bourgeois interior of the 1860 s to the 1890 s, with its gigantic sideboards distended with carvings, the sunless corners where palms stand, the balcony embattled behind its balustrade, and the long corridors with their singing gas flames, fittingly houses only the corpse. (Benjamin, pp. 48-49)

In Nights at the Circus, the corpse is the child-woman Mignon: made to mimic the living dead, weeping over the memory of her dead mother traced in her own portrait and beaten back into infancy by abuse.

The past is conjured in Nights at the Circus not to borrow its costumes but rather to dispense with them. Scenes are relived not to perpetuate their oppressive effects but to reform them; the return is made in the name of a departure. So it is in Marx's model that the imprisoning cycle of repetition must be exploded:

The social revolution of the nineteenth century cannot draw its poetry from the past, but only from the future. It cannot begin with itself before it has stripped offall superstition in regard to the past. Earlier revolutions required recollections of past world history in order to drug themselves concerning their own content. In order to arrive at its own content, the revolution of the nineteenth century must let the dead bury their dead. [...] Society now seems to have fallen back behind its point of departure; it has in truth first to create for itself the revolutionary point of departure, the situation, the relations, the conditions under which alone modern revolution becomes serious. ('Eighteenth Brumaire', pp. 98-99)

The narrative of Nights at the Circus falls back behind its point of departure in order to gather its forces for a revolutionary projection into the future. This point of departure is arrived at by shedding the past and by a necessary shattering of consciousness: Walser's kaleidoscopic vision is wiped clean as a slate, Fevvers's panorama fragmented. Hence, as Marx himselfindicates, this model of history serves as a model for a revolution in identity:

The reformation of consciousness only consists in letting the world enter one's consciousness, in waking up the world from the dream about itself, in explaining its own actions to itself [...]. Then it can be shown that it does not concern a large hyphen between past and future but the completion of the idea of the past. ${ }^{3 .}$ 
This 'completion of the idea of the past' is a function which Bloch attributes to the Utopian impulse and its 'anticipatory illumination' of the future in the past: as Christopher Norris writes, the ' "not yet" or token of unredeemed promise which he [Bloch] detected in every manifestation of past and present culture' (p. 242). Carter's purpose in returning to scenes of the past is to plunder it of its subversive content as it is concealed in the archaic or outmoded. ${ }^{36} \mathrm{Her}$ narrative returns to the past not only to exorcise its horrors but also to appropriate its Utopian anticipations of the future.

The 'spiralling tornado' (p. 295) oflaughter with which Carter's narrative ends gathers together in its progress the moments of ecstasy, vertigo, or disorientation in which time is suspended: the storm which blows the clowns 'off the face of the earth' (p. 243); the 'breath of stale night air' which 'ripple[s]' the seats and 'stroke[s]' the cherubs at the theatre as Fevvers limbers up for flight (p. 14); the 'wind of wonder' (p. 15) of the audience's awe; the beating of Fevvers's wings which 'ruffle' Walser's notes (p. 16); the 'sharp gusts' of scent and powder in Fevvers's dressing-room as she slams home a point of her narrative (p. 25); the swish of Fevvers's eyelashes which disturbs Walser's pages; the sound of beating wings which inspires Fevvers's first attempt at flight; the wind which sends Fevvers's hair into a 'wide flaxen arc' and threatens to 'whirl [her] away' (p. 90); the 'glow' and 'sizzle' of the baboushka's fire at the mention of St Petersburg (p. 96); the 'draught' which threatens to lift the Colonel's 'flimsy, impermanent, wonderful tent [. . . ] up and off (p. 100); the 'little spectral eddies and scurries' (p. 245) of windblown snow which herald the discovery of the Maestro's house; the 'wind of wonder' of the villagers' 'expelled breaths' which saves Fevvers in the shaman's god-hut (p. 290); the 'vertiginous sensation' (p. 87) which Walser experiences under the spell of Lizzie's suspension of time and in the presence of the Princess's and Mignon's music, the 'dizzying' sensation (p. 110) when looking into the Professor's eyes and, the 'erotic vertigo' (p. 143) prompted by Fevvers's presence.

Thus, the novel ends not with closure but on a threshold; Carter's 'storm of time' (p. 29) irresistibly recalls Benjamin's meditations on the storm of progress as depicted in Klee's 'Angelus Novus':

This is how one pictures the angel of history. His face is turned toward the past. Where we perceive a chain of events, he sees one single catastrophe which keeps piling wreckage upon wreckage and hurls it in front of his feet. The angel would like to stay, awaken the dead, and make whole what has been smashed. But a storm is blowing from Paradise; it has got caught in his wings with such violence that the angel can no longer close them. This storm irresistibly propels him into the future to which his back is turned, while the pile of debris before him grows skyward. This storm is what we call progress. ${ }^{37}$

"Fredric Jameson has described Bloch's philosophical project as proceeding by an 'expropriation of apparently alien or antagonistic cultural monuments' (Marxism and Form: Twentieth-Century Dialectical Theories of Literature (Princeton, NJ : Princeton University Press, 1971), p. 119).

'Theses on the Philosophy of History', in Illuminations, p. 249. 
Fevvers is Carter's 'angel of history': facing the devastation of the past, she is projected into the future by the storm of her own laughter.

I began by suspending the question of pastiche as the defining feature of the postmodern in order to address the question of time. However, the return and repetition enacted by pastiche might be understood as occupying a postmodern temporality. In his study of the neo-avant-garde, The Return of the Real, Hal Foster employs a psychoanalytic analogy: he suggests that the modernist shock of the new fulfils Lacan's account of trauma as a missed encounter with the real $;^{38}$ it is only in its traumatized repetition that the encounter is registered: 'If the historical avant garde was repressed institutionally, it was repeated in the first neo-avant-garde rather than, in the Freudian distinction, recollected, its contradictions worked through. ${ }^{139}$ Postmodern recoveries and returns, then, might be understood as a form of deferred action: 'Rather than break with the fundamental practises and discourses of modernity, the signal practices and discourses of postmodernity have advanced in a nachträglich relation to them' (p. 32).

In his discussion of postmodern culture, Fredric Jameson writes of the loss of the past, of the waning of affect and of blank parody (my italics): this evacuation of meaning might be understood as the symptoms of traumatized repetition. ${ }^{\circ 0}$ If critical distance is no longer possible, as Jameson argues, perhaps this is as much a problematic of time as of space. Moreover, in this sense, postmodern pastiche is not so much evading an encounter with history as disclosing it; what remains is the necessity of finding the forms of thought adequate to read its symptoms.

\footnotetext{
3* See Jacques Lacan, 'The Unconscious and Repetition', in The Four Fundamental Concepts of Psychoanalysis, ed. by Jacques-Alain Miller, trans, by Alan Sheridan (New York: Norton, 1973).

${ }^{30}$ The Return of the Real: The Avant Garde at the End of the Century, (Cambridge, M A : Massachusetts Institute of Technology Press, 1996), p. 21.

so Postmodernism or The Cultural Logic of Late Capitalism (London: Verso, 1991).
} 